\title{
CORRIGENDUM
}

\section{Comparison of different exposure settings in a case-crossover study on air pollution and daily mortality: counterintuitive results}

STEFANO ZAULI SAJANI, OTTO HÄNNINEN, STEFANO MARCHESI AND PAOLO LAURIOLA

Journal of Exposure Science and Environmental Epidemiology (2011) 21, 222; doi:10.1038/jes.2010.46

Correction to: Journal of Exposure Science and Environmental Epidemiology advance online publication, 23 June, 2010; doi:10.1038/jes.2010.27

After the above article was published online, one of the authors noticed that there was a mistake in the running head of the paper regarding the lead author's name.
The correct running head appears below:

Zauli Sajani et al.

Comparison of different exposure settings in a casecrossover study on air pollution and daily mortality. 